\title{
Inheritance and Gene Effect of Resistance to Mungbean Yellow Mosaic Virus (MYMV) in Mungbean [Vigna radiata (L.) Wilczek]
}

\begin{abstract}
Background: Mungbean Yellow Mosaic Virus is one of the major constraints in mungbean production. Knowledge of mode of inheritance and gene effects of MYMV resistance is very useful and effective for the development of genotypes resistant to disease or incorporation of resistance into the desirable promising genotypes whichlack of disease resistance.

Methods: In order to estimate inheritance pattern of MYMV disease resistance in mungbean, the study was conducted in summer season (2019) under natural condition. Six generations such as $\mathrm{P}_{1}, \mathrm{P}_{2}, \mathrm{~F}_{1}, \mathrm{BC}_{1}, \mathrm{BC}_{2}$ and $\mathrm{F}_{2}$ of six combinations [two resistant genotypes (7639 and 10266) and three susceptible genotypes (7621, 10257 and R-021018)] were studied inheritance pattern of resistance to MYMV in segregation population.

Result: Based on the result from mode of inheritance pattern of MYMV resistance, it can be concluded that single recessive gene is controlled the resistance of MYMV and susceptible behavior indicated as dominant over resistant. Additive gene action was the major role for the selection of MYMV resistance. Some differences in the expression of gene contributing for MYMV resistance from others findings might be attributed due to the sources of resistant genotypes which have different nature of resistant gene used in this investigation.
\end{abstract}

Key words: Inheritance, Mungbean, MYMV, Resistance.

\section{INTRODUCTION}

Mungbean Yellow Mosaic Virus (MYMV) is one of the most serious disease and severely occur in the sowing time of February, March and April in mungbean (Nay et al. 2008). White fly, Bemisia tabaci, is the vector which transmit the MYMV and insecticides application is ineffective under severe insect population (Malathi and John, 2008) and yield losses was found to the extent of $10-100 \%$ depending disease severity and crop growth stage (Nay et al. 2008 and Khattak et al. 2000).

The knowledge on inheritance pattern of resistance on MYMV is very important and useful to the identification of genes that will lead to the suitable breeding techniques and selection procedure for the varietal improvement program of mungbean. The inheritance pattern of MYMV resistance has been reported by many researcher in mungbean and described by a single recessive gene (Reddy, 2009 and Basak et al. 2004), a dominant gene (Sandhu et al. 1985), two recessive genes (Ammavasai et al. 2004 and Pal et al. 1991), complementary recessive genes (Shukla and Pandya, 1985) and two recessive genes governed MYMV resistance (Pal et al. 1991). However, the study of the selected parents lacking information on controlling gene action for MYMV resistance. Estimation of genetic effects or knowledge of gene action viz. additive, dominance and epistatic helps in the selection of parent to know the genetic cause of variability and to frame an efficient breeding strategy to be followed for the improvement of traits (Yadav et al. (2017); Narasimhulu et al. (2016); Khattak et al. (2001).
Department of Plant breeding, Physiology and Ecology, Yezin Agricultural University, Myanmar.

Corresponding Author: K.S. Win, Department of Plant breeding, Physiology and Ecology, Yezin Agricultural University, Myanmar. Email: kyawswarwin059@gmail.com

How to cite this article: Win, K.S., Win, S., Htun, T.M., Win, N.K.K. and Oo, K.S. (2021). Inheritance and Gene Effect of Resistance to Mungbean Yellow Mosaic Virus (MYMV) in Mungbean [Vigna radiata (L.) Wilczek]. Legume Research. 44(4): 486-490. DOI: 10.18805/LR-572.

Submitted: 09-06-2020 Accepted: 04-09-2020 Online: 10-11-2020

Generation mean analysis (Mather and Jinks (1982); Mather and Jinks (1971); Hayman (1958); Jinks and Jones (1958) provides the information about the relative importance of effects of different gene actions viz., additive and dominance with an unambiguous test for epistasis. Moreover, generation mean analysis is a simple and useful technique for the estimation of type of epistasis viz., additive $\times$ additive, additive $\times$ dominance and dominance $\times$ dominance operating in the inheritance of a character. Therefore, this study was conducted to investigate the inheritance pattern of resistance to MYMV in segregation population and determine types of gene action for the improvement of mungbean breeding program.

\section{MATERIALS AND METHODS}

The study was conducted at Food Legumes Section, Department of Agricultural Research (DAR), Yezin, Myanmar 
(19 $51^{\prime} \mathrm{N}$ latitude and $96^{\circ} 7^{\prime} \mathrm{E}$ longitude at $97 \mathrm{~m}$ altitude) in summer (February-May, a hot spot season for MYMV disease), 2019. The materials of this study were consisted of five mungbean genotypes, viz. two resistant genotypes (7639 and 10266) and three susceptible genotypes (7621,

Table 1: Origin and disease reaction of parental genotypes.

\begin{tabular}{lccc}
\hline Genotype & Origin & $\begin{array}{c}\text { Name } \\
\text { of } \\
\text { Cultivar }\end{array}$ & $\begin{array}{c}\text { MYMV } \\
\text { disease } \\
\text { reaction }\end{array}$ \\
\hline 7621 & AVRDC & VC-1973-A & HS \\
10257 & Myanmar & Shwewar, Kyaikto & HS \\
R-021018 & Seed Bank, DAR & - & HS \\
7639 & Philippine & M-28 & HR \\
10266 & Myanmar & Pedishwewar, Salin & HR \\
\hline
\end{tabular}

10257 and $\mathrm{R}-021018)$ to develop $F_{1}, F 2, B_{1}\left(F_{1} P_{1}\right)$ and $B C_{2}$ $\left(F_{1} P_{2}\right)$. Origin, disease reaction and some good characters of parental genotypes were presented in Table 1. These resistant genotypes and susceptible varieties were crossed by the procedure of Khattak et al. (1998) and each cross combination $\left(F_{1}\right)$ raised as $F_{2}, B C_{1}\left(F_{1} P_{1}\right)$ and $B C_{2}\left(F_{1} P_{2}\right)$. The six basic populations, namely $\mathrm{P}_{1}, \mathrm{P}_{2}, \mathrm{~F}_{1}, \mathrm{BC}_{1}, \mathrm{BC}_{2}$ and $\mathrm{F}_{2}$ of each combination will be grown in compact family block design with three replications. Each plot consisted of 3-m rows with inter and intra row spacing of 30 and $10 \mathrm{~cm}$, respectively. The parents $\left(\mathrm{P}_{1}, \mathrm{P}_{2}\right), \mathrm{F}_{1}, \mathrm{BC}_{1}\left(\mathrm{~F}_{1} \times \mathrm{P}_{1}\right)$ and $\mathrm{BC}_{2}$ $\left(F_{1} \times P_{2}\right)$ were sown in single row with $3 \mathrm{~m}$ long (30 plants) and 5 row (150 plants) in $F_{2}$ for one family. All recommended cultural practices were followed, except insecticide is not spraying to allow the growth and development of vector Bemecia tabaci. Disease reaction of mungbean yellow

Table 2: Reaction to mungbean yellow mosaic virus (MYMV) in six generations of six mungbean crosses.

\begin{tabular}{|c|c|c|c|c|c|c|c|c|c|c|c|}
\hline \multirow{2}{*}{ Generation } & \multicolumn{3}{|c|}{ Resistant } & \multicolumn{3}{|c|}{ Susceptiple } & \multirow{2}{*}{ Ratio } & \multicolumn{2}{|c|}{ Observed } & \multirow{2}{*}{$\chi^{2}$} & \multirow{2}{*}{ Prob } \\
\hline & $\mathrm{HR}$ & $\mathrm{R}$ & MR & MS & $S$ & $\mathrm{HS}$ & & $\mathrm{R}$ & $S$ & & \\
\hline 7621 & 0 & 0 & 0 & 0 & 0 & 89 & & & 89 & & \\
\hline 7639 & 84 & 1 & 1 & 2 & 1 & 0 & & 86 & 3 & & \\
\hline $\mathrm{F} 1$ & 0 & 0 & 0 & 0 & 3 & 98 & & & 101 & & \\
\hline $\mathrm{F} 2$ & 87 & 1 & 20 & 5 & 31 & 293 & $1: 3$ & 108 & 329 & 0.02 & 0.89 \\
\hline $\mathrm{BC} 1$ & 6 & 0 & 0 & 0 & 1 & 104 & & 6 & 105 & & \\
\hline BC2 & 45 & 0 & 5 & 3 & 7 & 55 & $1: 1$ & 50 & 65 & 1.96 & 0.16 \\
\hline 10257 & 0 & 0 & 0 & 0 & 0 & 69 & & & 69 & & \\
\hline 7639 & 56 & 0 & 0 & 0 & 0 & 2 & & 56 & 2 & & \\
\hline $\mathrm{F} 1$ & 0 & 0 & 0 & 0 & 0 & 72 & & & 72 & & \\
\hline $\mathrm{F} 2$ & 52 & 0 & 12 & 2 & 20 & 160 & $1: 3$ & 64 & 182 & 0.14 & 0.71 \\
\hline $\mathrm{BC} 1$ & 16 & 0 & 1 & 1 & 1 & 55 & & 17 & 57 & & \\
\hline $\mathrm{BC} 2$ & 33 & 0 & 1 & 0 & 6 & 27 & $1: 1$ & 34 & 33 & 0.01 & 0.90 \\
\hline R-021018 & 0 & 0 & 0 & 0 & 0 & 45 & & & 45 & & \\
\hline 7639 & 57 & 0 & 0 & 0 & 0 & 0 & & 57 & & & \\
\hline $\mathrm{F} 1$ & 0 & 0 & 0 & 0 & 0 & 53 & & & 53 & & \\
\hline $\mathrm{F} 2$ & 35 & 0 & 5 & 6 & 20 & 158 & $1: 3$ & 40 & 184 & 6.09 & 0.01 \\
\hline $\mathrm{BC} 1$ & 0 & 0 & 0 & 0 & 0 & 48 & & & 48 & & \\
\hline $\mathrm{BC} 2$ & 28 & 0 & 2 & 3 & 4 & 31 & $1: 1$ & 30 & 38 & 0.94 & 0.33 \\
\hline 7621 & 0 & 0 & 0 & 0 & 0 & 47 & & & 47 & & \\
\hline 10266 & 48 & 0 & 0 & 0 & 0 & 0 & & 48 & & & \\
\hline $\mathrm{F} 1$ & 0 & 0 & 1 & 0 & 0 & 47 & & & 47 & & \\
\hline F2 & 35 & 0 & 1 & 3 & 22 & 121 & $1: 3$ & 36 & 146 & 2.64 & 0.10 \\
\hline $\mathrm{BC} 1$ & 1 & 0 & 0 & 0 & 1 & 54 & & 1 & 55 & & \\
\hline $\mathrm{BC} 2$ & 24 & 0 & 0 & 0 & 4 & 24 & $1: 1$ & 24 & 28 & 0.32 & 0.56 \\
\hline 10257 & 0 & 0 & 0 & 0 & 0 & 89 & & & 89 & & \\
\hline 10266 & 86 & 0 & 1 & 0 & 0 & 0 & & 87 & & & \\
\hline $\mathrm{F} 1$ & 2 & 0 & 0 & 0 & 0 & 112 & & 2 & 112 & & \\
\hline $\mathrm{F} 2$ & 76 & 0 & 13 & 9 & 49 & 254 & $1: 3$ & 88 & 313 & 2 & 0.16 \\
\hline $\mathrm{BC} 1$ & 1 & 0 & 0 & 0 & 0 & 93 & & 1 & 93 & & \\
\hline $\mathrm{BC} 2$ & 37 & 0 & 2 & 0 & 10 & 31 & $1: 1$ & 39 & 41 & 0.05 & 0.82 \\
\hline R-021018 & 0 & 0 & 0 & 0 & 0 & 75 & & & 75 & & \\
\hline 10266 & 57 & 0 & 0 & 0 & 0 & 0 & & 57 & & & \\
\hline $\mathrm{F} 1$ & 0 & 0 & 0 & 0 & 1 & 77 & & & 78 & & \\
\hline F2 & 51 & 0 & 9 & 11 & 27 & 194 & $1: 3$ & 60 & 232 & 3.08 & 0.08 \\
\hline $\mathrm{BC} 1$ & 0 & 0 & 0 & 0 & 0 & 84 & & & 84 & & \\
\hline $\mathrm{BC} 2$ & 27 & 0 & 2 & 1 & 2 & 33 & $1: 1$ & 29 & 36 & 0.75 & 0.38 \\
\hline
\end{tabular}


mosaic virus was recorded at 60 days after sowing (when $95 \%$ of the spreader rows (Yezin-9) showed MYMV incidence) under field conditions. The tested populations were classified into six reactions that is, highly susceptible (HS), susceptible (S), moderately susceptible (MS), moderately resistant (MR), resistant $(\mathrm{R})$ and highly resistant (HR) on the basis of disease scores and type of symptoms by estimating the average score for the top 5 leaves of each plant within each lines at 60 days after planting by Nair et al. (2017). The plants in the $F_{2}$ and back cross generations will be classified as resistant (1-3) and susceptible (4-6) following Reddy and Singh (1993).

\section{Statistical Analysis}

The chi-square test was performed to determine the goodness of fit of observed segregation for MYMV disease reaction in $F_{2}$ and test cross generations for the inheritance pattern of MYMV. The generation mean analysis was performed for the estimation of genetic components by scaling test for A, B, C and D scales as suggested by Mather and Jinks (1971) and Hayman and Mather (1955) and joint scaling test by Cavalli (1952) and estimation of gene effects by the model of the model of Jinks and Jones (1958). The minimum number of gene or number of effective factors controlling resistance was estimated by three methods: Method 1 was proposed by Wright (1968); Methods 2 and 3 were proposed by Lande (1981).

\section{RESULTS AND DISCUSSION}

The number of plants, disease reaction and chi square value of parent 1 , parent $2, \mathrm{~F}_{1}, \mathrm{~F}_{2}, \mathrm{BC}_{1}$ and $\mathrm{BC}_{2}$ of six crosses were presented in Table 2. According to the results, the $F_{1}$ of all six crosses obviously showed that susceptibility to MYMV was dominant over resistance and no maternal effect on the inheritance pattern of MYMV in mungbean. This finding was very close agreement with the research of Khattak et al. (2000) and Shukla et al. (1978) in mungbean. Moreover, the segregation ratio of $\mathrm{F}_{2}$ and $\mathrm{BC}_{2}$ was observed with 1R:3S and 1R:1S, respectively and all these crosses verified that it is a single recessive gene inherited character with dominance effect of susceptibility over resistance to MYMV. The pattern of monogenic recessive inheritance for MYMV has been reported by Sandhiya and Saravanan
(2020); Basavaraja et al. (2017); Sai et al. (2017); Jain et al. (2013); Reddy, (2009). There are, however, many research findings that documented with monogenic dominant gene (Gupta et al. (2005); Sandhu et al. (1985), two recessive genes (Alam et al. (2014); Singh et al. (2013); Dhole and Reddy (2012), complementary recessive genes (Thamodhran et al. (1988) and Shukla and Pandya (1985) and two dominant genes (Mahalingam et al. (2018) and Murugan and Nadarajan (2012).

The result of scaling and joint scaling test by Mather (1949) and Cavalli (1952) for the present or absence of gene interaction was shown in Table 3 . The research revealed that the scaling test $A, B, C$ and $D$ were not significant from zero in all crosses except from $10257 \times 7639$ and R-021018 $\times 7639$. This indicated that the presence of additive $\times$ dominance interaction in $10257 \times 7639$ and dominance $\times$ dominance interaction in $21018 \times 7639$, respectively. However, when the results were subjected to confirm for the scaling test by joint scaling test, all the crosses were found with non-significant values of chi square test. The range of chi square values from the estimate of MYMV was 0.74 and 6.74 , respectively. All the values were less than the 0.05 at $\mathrm{df}=3(7.81)$. Therefore, this is clearly indicated that resistance of MYMV was controlled by allelic gene action with no epistatic gene interaction and revealed the adequacy of the simple additive-dominance model which is appropriate to describe the inheritance of MYMV in the respective cross.

Genetic effects viz, $\mathrm{m}, \mathrm{d}$ and $\mathrm{h}$ for resistance of MYMV in six mungbean crosses were presented in Table 4 according to the three parameter model by Jinks and Jones (1958). The mid parent value was significant in all crosses and expressed with the value of $3.58,3.78,4.19,3.96,3.77$ and 3.45 in the cross of $7621 \times 7639,10257 \times 7639$, R$021018 \times 7639,7621 \times 10266,10257 \times 10266$ and $R-$ $021018 \times 10266$, respectively. This finding pointed that this MYMV resistance was quantitatively inherited. The three parameter model pronounced that only additive gene effect was found in all crosses and more pronounced significant with the value of $2.42,2.40,2.48,2.44,2.47$ and 2.48 in the cross of $7621 \times 7639,10257 \times 7639, \mathrm{R}-021018 \times 7639$, $7621 \times 10266,10257 \times 10266$ and R-021018 × 10266, respectively while the no significant dominance gene effects

Table 3: Estimate of scaling and joint scaling test for MYMV resistance in six crosses of mungbean.

\begin{tabular}{lrrrrr}
\hline \multirow{2}{*}{ Cross } & \multicolumn{2}{c}{ Scaling test } & \multicolumn{2}{c}{ Joint scaling } \\
\cline { 2 - 5 } & \multicolumn{1}{c}{ A } & \multicolumn{1}{c}{ B } & C & D & test $\left(\chi^{2}\right)$ \\
\hline $762 \times 7639$ & $-0.5 \pm 0.59$ & $0.49 \pm 0.46$ & $0.01 \pm 0.73$ & $0.008 \pm 0.34$ & $6.47^{\mathrm{ns}}$ \\
$10257 \times 7639$ & $-\mathbf{0 . 1 7 ^ { \star * } \pm 0 . 0 9}$ & $-0.34 \pm 0.62$ & $-0.31 \pm 0.54$ & $0.10 \pm 0.40$ & $4.66^{\mathrm{ns}}$ \\
$\mathrm{R}-021018 \times 7639$ & $-0.02 \pm 0.05$ & $0.40 \pm 0.59$ & $\mathbf{1 . 0 6} 6^{\star *} \pm 0.49$ & $0.34 \pm 0.38$ & $5.42^{\mathrm{ns}}$ \\
$7621 \times 10266$ & $-0.09 \pm 1.84$ & $0.23 \pm 3.47$ & $0.60 \pm 5.77$ & $0.23 \pm 3.30$ & $1.41^{\mathrm{ns}}$ \\
$10257 \times 10266$ & $0.03 \pm 0.12$ & $0.04 \pm 0.54$ & $0.35 \pm 0.41$ & $0.14 \pm 0.33$ & $0.74^{\mathrm{ns}}$ \\
R-021018 $\times 10266$ & $0.03 \pm 0.03$ & $0.55 \pm 0.61$ & $0.51 \pm 0.45$ & $-0.03 \pm 0.37$ & $2.74^{\mathrm{ns}}$ \\
\hline
\end{tabular}

$\mathrm{A}, \mathrm{B}, \mathrm{C}$ and $\mathrm{D}=$ Scales used to identify the presence/absence of epistasis; $\mathrm{ns}=$ non-significant; ${ }^{* *}=$ significant and highly significant at 0.01 probability levels, respectively. 
Table 4: Gene effect for MYMV resistance in six crosses of mungbean by three parameter model by Jinks and Jones (1958).

\begin{tabular}{|c|c|c|c|}
\hline Cross & $\mathrm{m}$ & $d$ & $\mathrm{~h}$ \\
\hline $7621 \times 7639$ & $3.58^{* *} \pm 0.68$ & $2.42^{* \star} \pm 0.04$ & $2.36 \pm 1.75$ \\
\hline $10257 \times 7639$ & $3.78^{\star \star} \pm 0.80$ & $2.40^{* *} \pm 0.06$ & $1.47 \pm 2.08$ \\
\hline R-021018 × 7639 & $4.19^{\star *} \pm 0.76$ & $2.48^{* *} \pm 0.01$ & $1.48 \pm 1.99$ \\
\hline $7621 \times 10266$ & $3.96^{\star *} \pm 0.91$ & $2.44^{* *} \pm 0.03$ & $1.67 \pm 2.41$ \\
\hline $10257 \times 10266$ & $3.77^{* *} \pm 0.67$ & $2.47^{* *} \pm 0.02$ & $1.92 \pm 1.81$ \\
\hline $\mathrm{R}-021018 \times 10266$ & $3.45^{\star *} \pm 0.75$ & $2.48^{* *} \pm 0.01$ & $3.14 \pm 2.01$ \\
\hline
\end{tabular}

$\mathrm{m}=$ mid parent value, $\mathrm{d}=$ Additive effect, $\mathrm{h}=$ Dominance effect and ${ }^{* *}=$ significant and highly significant at 0.01 probability levels, respectively.

Table 5: Effective factor of gene for resistance of MYMV in six mungbean crosses.

\begin{tabular}{lcccccc}
\hline Effect & $7621 \times 7639$ & $10257 \times 7639$ & R- $021018 \times 7639$ & $7621 \times 10266$ & $10257 \times 10266$ & R-021018×10266 \\
\hline EF1 & 1.09 & 1.05 & 1.38 & 1.18 & 1.20 & 0.86 \\
EF2 & 0.75 & 0.74 & 0.92 & 0.81 & 0.86 \\
EF3 & 0.43 & 0.49 & 0.54 & 0.46 & 0.52 \\
Mean & 0.75 & 0.76 & 0.95 & 0.82 & 0.86 \\
\hline
\end{tabular}

were observed in all crosses. The plus sign in the additive gene effect implies that $P_{1}$ contributes positively to the trait as compared to $P_{2}$ and vice versa. This finding was more closely related with the results of gene effects for powdery mildew in mungbean and late leaf spot in groundnut by Wambi et al. (2014) and Sorajjapinun et al. (2005) who observed that additive gene action was a major role in controlling powdery mildew resistance in mungbean and late leaf spot in groundnut. The estimates of effective factor or minimum number of gene for resistance of MYMV in six mungbean crosses ranged from 0.43-1.09, 0.49-1.05, 0.54 $-1.38,0.46-1.18,0.52-1.20$ and $0.53-1.27$ in the cross of $7621 \times 7639,10257 \times 7639, \mathrm{R}-021018 \times 7639,7621 \times$ $10266,10257 \times 10266$ and R-021018 $\times 10266$, respectively (Table 5). The average number of effective factor was found with below one in all crosses of this study. Therefore, the resistance of MYMV was governed by only one gene. However, MYMV resistance in mungbean was controlled by at least two genes according to the findings of Alam et al. (2014) and Singh et al. (2013), respectively.

\section{CONCLUSION}

Based on the result of this study, it can be concluded that additive gene action was the major role for the selection of MYMV resistance. Susceptible behavior indicated as dominant over resistant and single recessive gene that controlled for the resistance of MYMV. Therefore, the knowledge of mode of inheritance and gene effects of MYMV resistance is very useful and effectively for the development of genotypes resistant to disease or incorporation of resistance into the desirable promising genotypes which have lack of disease resistance. The expression of gene contributing for MYMV resistance from others findings might be attributed due to the sources of resistant genotypes which have different nature of resistant gene used in this investigation.

\section{REFERENCES}

Alam, A.M., Somta, P. and Srinives, P. (2014). Generation mean and path analyses of reaction to mungbean yellow mosaic virus (MYMV) and yield-related traits in mungbean [Vigna radiata (L.) Wilczek]. SABRAO Journal of Breeding and Genetics. 46(1): 150-159.

Ammavasai, S., Phogat, D.S. and Solanki, I.S. (2004). Inheritance of resistance to mungbean yellow mosaic virus (MYMV) in green gram [Vigna radiata (L.) Wilczek]. The Indian Journal of Genetics and Plant Breeding. 64(2): 146-146.

Basak, J., Kundagrami, S., Ghose, T.K. and Pal, A. (2004). Development of yellow mosaic virus (YMV) resistance linked DNA marker in Vigna mungo from populations segregating for YMV-reaction. Molecular Breeding. 14(4): 375-383.

Basavaraja, T., Niranjana, M., Shashi, P.K. and Satheesh Naik, S.J. (2017). Inheritance of resistance to Mungbean Yellow Mosaic Virus (MYMV) in intra and inter specific crosses of Vigna. Journal of Food Legumes. 30(1): 15-19.

Cavalli L.L. (1952). An analysis of linkage in quantitative inheritance. In: Quantitative Inheritance, [(ed.) E.C.R. Reevee and C.H. Waddington], HMSO, London, pp. 135-144.

Dhole, V.J. and Reddy, K.S. (2012). Genetic analysis of resistance to mungbean yellow mosaic virus in mungbean (Vigna radiata). Plant Breeding. 131(3): 414-417.

Gupta, S., Kumar, S., Singh, R.A. and Chandra, S. (2005). Identification of a single dominant gene for resistance to Mungbean Yellow Mosaic Virus in blackgram [Vigna mungo (L.) Hepper]. SABRAO Journal of Breeding and Genetics. 37(2): 85-89.

Hayman, B.I. (1958). Separation of epistasis from additive and dominance variation in generation means. Heredity. 12 : 371-391.

Hayman, B.J. and Mather, K. (1955). The description of genetic interaction in continuous variation. Biometrics. 11: 69-82.

Jain, R.A.S.H.M.I., Lavanya, G.R., Reddy, P.A. and Babu, G.S. (2013). Genetic inheritance of yellow mosaic virus resistance in mungbean [Vigna radiata (L.) Wilczek]. Trends Biosci. 6: 305-06. 
Jinks, J.L. and Jones, R.M. (1958). Estimation of components of heterosis. Genetics. 43: 223-234.

Khattak, G.S.S., Haq, M.A., Ashraf, M. and Elahi, T. (2000). Genetics of Mungbean Yellow Mosaic Virus (MYMV) in mungbean [Vigna radiata (L.) Wilczek]. Journal of Genetics and Breeding. 54(4): 237-243.

Khattak, G.S.S., Haq, M.A., Rana, S.A., Elahi, T. and Srinives, P. (1998). Efficient technique for crossing mungbean [Vigna radiata (L.) Wilczek]. Thai Journal of Agricultural Science (Thailand). 31(4): 577-582.

Khattak, G.S.S., Haq, M.A., Ashraf, M. and Mc Neilly, T. (2001). Genetic basis of variation in yield and yield components mungbean [Vigna radiata (L.) Wilczek]. Heriditas. 13(4): 211-217.

Lande, R. (1981). The minimum number of genes contributing to quantitative variation between and within populations. Genetics. 99(3-4): 541-553.

Mahalingam, A., Satya, V.K., Manivannan, N., Narayanan, S.L. and Sathya, P. (2018). Inheritance of mungbean yellow mosaic virus disease resistance in greengram [Vigna radiata (L.). Wilczek]. International Journal of Current Microbiology and Applied Sciences. 7(1): 880-885.

Malathi, V.G. and John, P. (2008b). Mungbean Yellow Mosaic Viruses. In: Desk Ency-clopedia of Plant and Fungal Virology in Encyclopedia of Virology, [Mahy, B.W.J., Van Regenmortel, M.H.V., (eds)]. Amsterdam: Elsevier. Vol. 8. p. 364-371.

Mather, K. (1949). Biomertrical Genetics. Dover Publication, Inc., New York.

Mather, K. and Jinks J.L. (1971). Biometrical Genetics. $3^{\text {rd }}$ edition, Chapman and Hall, London.

Mather, K. and Jinks, J.L. (1982). In: Biometrical Genetics, third ed. Chapman and Hall Ltd., ISBN-10, 0412228904.

Murugan, E. and Nadarajan, N. (2012). Genetic studies on differential expression of mungbean yellow mosaic virus resistance related to trichome density in urd bean [Vigna mungo (L.) Hepper]. Indian Journal of Plant Genetic Resources. 25(2): 135-138.

Nair, R.M., Götz, M., Winter, S., Giri, R.R., Boddepalli, V.N., Sirari, A., Bains, T.S. Taggar, G. K., Dikshit, H.K., Aski, M., Boopathi, M., Swain, D., Rathore, A., Kumar, V.A.E., Lii, C. and Kenyon, L. (2017). Identification of mungbean lines with tolerance or resistance to yellow mosaic in fields in India where different begomovirus species and different Bemisia tabaci cryptic species predominate. European Journal of Plant Pathology. 149(2): 349-365.

Narasimhulu, R., Naidu, N.V. and Reddy, K.H.P. (2016). Genetic analysis for yield and yield attributes in greengram [Vigna radiata (L.) Wilczek]. Legume Research. 41(3):349-355. DOI: $10.18805 /$ LR-3768.

Nay, N.O., Myint, Y. and Maung, M.T. (2008). Determination of Varietal Resistance and Effect of Sowing Time on the Severity of Mungbean Yellow Mosaic Disease. Proceedings of the Seventh Annual Research Conference (Agricultural Science). 347-363.
Pal, S.S., Dhaliwal, H.S. and Bains, S.S. (1991). Inheritance of resistance to yellow mosaic virus in some Vigna species. Plant Breeding. 106(2): 168-171.

Reddy, K.R. and Singh, D.P. (1993). Inheritance of resistance to mungbean yellow mosaic virus. Madras Agricultural Journal. 80: 199-201.

Reddy, K.S. (2009). A new mutant for yellow mosaic virus resistance in Mungbean [Vigna radiata (L.) Wilczek] variety SML668 by Recurrent Gamma-ray Irradiation. Induced Plant Mutation in the Genomics Era, Food and Agriculture Organization of the United Nations, Rome. 361-362.

Sai, C.B., Nagarajan, P., Raveendran, M., Rabindran, R. and Senthil, $N$. (2017). Understanding the inheritance of mungbean yellow mosaic virus (MYMV) resistance in mungbean [Vigna radiata (L.) Wilczek]. Molecular Breeding. 37(5): 1-15.

Sandhu, T.S., Brar, J.S., Sandhu, S.S. and Verma, M.M. (1985). Inheritance of resistance to mungbean yellow mosaic virus in green-gram. Journal of Research PAU. 22: 607-611.

Sandhiya, V. and Saravanan, S. (2020). Genotypic analysis for retrieval of mymv resistant progenies from certain crosses of mungbean [Vigna radiata (L.) Wilczek]. Indian Journal of Agricultural Research. 54(4): 511-515.

Shukla, G.P. and Pandya, B.P. (1985). Resistance to yellow mosaic in greengram. SABRAO Journal of Breeding and Genetics. 17: 165-171.

Shukla, G.P., Pandya, B.P. and Singh, D.P. (1978). Inheritance of Resistance to yellow mosaic in mungbean. Indian Journal of Genetics and Plant Breeding (The). 38(3): 357-360.

Singh, G., Singh, S. and Sheoran, O.P. (2013). Inheritance of Mungbean Yellow Mosaic Virus (MYMV) resistance in mungbean [Vigna radiata (L.) Wilczek]. Legume Research: An International Journal. 36(2): 131-137.

Sorajjapinun, W., Rewthongchum, S., Koizumi, M. and Srinives, P. (2005). Quantitative inheritance of resistance to powdery mildew disease in mungbean [Vigna radiata (L.) Wilczek]. SABRAO Journal of Breeding and Genetics. 37(2): 91.

Thamodhran, G., Geetha, S. and Ramalingam, A. (2016). Genetic study in urdbean [Vigna mungo (L.) Hepper] for inheritance of mungbean yellow mosaic virus resistance. International Journal of Agriculture Environment and Biotechnology. 9(1): 33-37.

Wambi, W., Tukamuhabwa, P., Puppala, N., Okello, D.K., Nalugo, R.G. and Kaaya, N.A. (2014). Narrow sense heritability and gene effects for late leaf spot resistance in Valencia groundnuts. African Crop Science Journal. 22(4): 327-336.

Wright, S. (1968). The Genetics of Qualitative Variability. In: Evaluation and Genetics of Populations Genetic and Biometric Foundations. Chicago IL University of Chicago Press. 42: $1324-1330$.

Yadav, S.M., Prakash, Ved and Khedar, O.P. (2017). Generation mean analysis for yield and its components in green gram [Vigna radiata (L.) Wilczek]. Plant Archives. 17(2): 13611367. 